\title{
Reassessment of the Unbound Concentrations of Unconjugated Bilirubin in Relation to Neurotoxicity In Vitro
}

\author{
J. DONALD OSTROW, LORELLA PASCOLO, AND CLAUDIO TIRIBELLI
}

Research Service (151L), VA Puget Sound Health Care System, Seattle, Washington 98108-1597, U.S.A., and the GI/Hepatology Division, Department of Medicine, University of Washington School of Medicine, Seattle, Washington 98195, U.S.A. [J.D.O.]; and the Liver Study Center, University of Trieste, I-34012

Trieste, Italy [L.P., C.T.]

\begin{abstract}
Most studies of the cellular toxicity of unconjugated bilirubin (UCB) have been performed at concentrations of unbound UCB $\left(\mathrm{B}_{\mathrm{F}}\right)$ that exceed those in the plasma of neonates with bilirubin encephalopathy. We assessed whether UCB could be toxic to neurons and astrocytes at clinically relevant $\mathrm{B}_{\mathrm{F}}$ values $(\leq 1.0$ $\mu \mathrm{M}$ ), a range in which spontaneous precipitation of UCB would be unlikely to occur, even though $\mathrm{B}_{\mathrm{F}}$ exceeded the aqueous saturation limit of $70 \mathrm{nM}$. A meta-analysis yielded twelve published studies that had determined the in vitro effects of UCB on the function of cultured neurons or astrocytes at calculable $B_{F}$ values $\leq 1.0 \mu \mathrm{M}$. $\mathrm{B}_{\mathrm{F}}$ values were recalculated from the stated $\mathrm{UCB}$, albumin, and chloride concentrations by applying affinity constants derived from ultrafiltration of comparable solutions containing ${ }^{14} \mathrm{C}-\mathrm{UCB}$ and delipidated human serum albumin. At $\mathrm{B}_{\mathrm{F}}$ slightly above aqueous solubility, UCB impaired mitochondrial function and viability of astrocytes. Exposure of neuroblastoma and embryonic neuronal cell lines to $B_{F}$ above $250 \mathrm{nM}$ impaired cellular proliferation and mitochondrial function and increased apoptosis. Purified UCB inhibited the uptake of glutamate into astrocytes at $\mathrm{B}_{\mathrm{F}}$ as low as $309 \mathrm{nM}$ and induced
\end{abstract}

ABSTRACT

apoptosis in brain neurons at $\mathrm{B}_{\mathrm{F}}$ as low as $85 \mathrm{nM}$. UCB can impair various cellular functions of astrocytes and neurons exposed to $\mathrm{B}_{\mathrm{F}}$ near or modestly above its aqueous solubility limit, at which UCB exists as soluble oligomers and metastable microaggregates. The results render doubtful the long-held concept that precipitation of UCB in or on cells is required to produce neurotoxicity. (Pediatr Res 54: 98-104, 2003)

UCB, unconjugated bilirubin

\section{Abbreviations}

$\mathbf{B}_{\mathbf{F}}$, concentration of free (unbound) UCB

$\mathbf{B}_{\mathbf{T}}$, total UCB concentration

HSA, human serum albumin

$\mathbf{K}_{\mathbf{F}}$, corrected affinity constant of HSA for UCB

MTT, 3-(4,5-dimethylthiazol-2-yl)-2,5-diphenyltetrazolium bromide

DMEM, Dulbecco's Minimal Essential Medium

LDH, lactate dehydrogenase

$\mathbf{T}_{\mathbf{3}}$, triiodothyronine

DAPI, 4', 6-diamidino-2-phenylindole
The moderate "physiologic" jaundice that develops after birth may be neuroprotective for the neonate (1), owing to the potent antioxidant properties of UCB $(2,3)$. By contrast, if the underlying immaturity of the hepatic transport processes or the postnatal increases in production and enterohepatic circulation of UCB are more severe (4), marked neonatal jaundice occurs, which may result in reversible neurotoxicity (bilirubin encephalopathy) $(5,6)$. This may progress to precipitation of UCB in

Received July 23, 2002; accepted February 17, 2003.

Correspondence: Jay Donald Ostrow, M.D., Research Service (151L), VA Puget Sound Health Care System, Seattle Division, 1660 South Columbian Way, Seattle WA 191081597, U.S.A.; e-mail: jdostrow@medicine.washington.edu

L.P. and C.T. were supported in part by grants from the Italian Ministry for Scientific Research, the Italian Ministry of Health (ICS060.1/RF98.67), the University of Trieste, and from the Foundation for the Study of the Liver, Trieste (FCTR00/01).

DOI: 10.1203/01.PDR.0000067486.79854.D5 focal areas of the CNS with permanent neurologic damage (kernicterus) (5).

The UCB that enters the CNS is derived from the free fraction of plasma UCB $\left(B_{F}\right)$ that is not bound to plasma proteins and lipoproteins $(6)$. $B_{F}$ levels in plasma are normally very low, as a result of the tight binding of UCB to two sites on HSA (7). Recent data indicate that the affinity for UCB decreases markedly as HSA concentration increases $(8,9)$ and when chloride is added (9). Therefore, the accepted affinity constant of $6 \times 10^{7} \mathrm{~L} / \mathrm{mol}$ (10), determined at an HSA concentration of $60 \mu \mathrm{M}$, overestimates by an order of magnitude the true affinity constant at physiologic albumin and chloride concentrations (9), with consequent marked underestimation of $\mathrm{B}_{\mathrm{F}}$. In addition, most published studies of the neurotoxicity of UCB have been performed at total UCB levels vastly higher than those seen in jaundiced neonates with 
reversible bilirubin encephalopathy, and thus have questionable relevance to the clinical manifestations of neurotoxicity $(11,12)$.

In the present work, we have applied the affinity constants of UCB for HSA $\left(K_{F}\right)$, derived by serial ultrafiltration (9), to recalculate the $\mathrm{B}_{\mathrm{F}}$ levels present in published in vitro studies of UCB toxicity to neurons and astrocytes. Our aim was to test the hypothesis that in vitro neurotoxicity of UCB could be observed at $\mathrm{B}_{\mathrm{F}}$ values of $1.0 \mu \mathrm{M}$ or less, in the range at which spontaneous precipitation of UCB would be unlikely to occur, even if $B_{F}$ was above the aqueous saturation limit of $70 \mathrm{nM}$. In 12 studies performed at relevantly low total UCB concentrations, toxicity usually occurred at $\mathrm{B}_{\mathrm{F}}$ levels near or modestly above the aqueous solubility of UCB.

\section{METHODS}

Selection of papers for meta-analysis. We searched PubMed for papers under the following headings: bilirubin + (cells, cultured or cell lines) + (astrocytes or neurons). After eliminating duplicates and adding two related papers by Silberberg et al. (12a,b), we had 28 references. Of these, all but 12 were eliminated for the following reasons: paper published in Chinese 1; review article without original data, 1; did not perform in vitro incubations with $\mathrm{UCB}, 5$; data duplicated results in a paper by the same group that was selected for meta-analysis, 1 ; only uptake and binding of UCB were studied, not toxicity, 1; incubations included whole human or bovine serum, or BSA, precluding estimation of $\mathrm{B}_{\mathrm{F}}$ values by applying our ultrafiltration-derived $\mathrm{K}_{\mathrm{F}}$ values for binding of UCB to delipidated HSA, 4 (also, in two of these, the source and purity of UCB were not given, one studied only UCB photodegradation products, and one performed studies only at $B_{F}$ values of $\geq 5 \mu \mathrm{M}$ ); studies were done only at $B_{F}$ values of $5 \mu \mathrm{M}$ or greater, 2; studies were done at $\mathrm{B}_{\mathrm{F}}$ values below 5 $\mu \mathrm{M}$, but examined only recovery of function after bilirubin washout and the control data duplicated results in another paper by the same group, 1 .

One of the 12 papers selected one was done only at a single $\mathrm{B}_{\mathrm{F}}$ value of $0.5 \mu \mathrm{M}$ in the absence of albumin (13), and in part duplicated data from another paper by the same group (14) that was performed over a range of $B_{F}$ values. In another selected paper (15), studies were done at $\mathrm{B}_{\mathrm{F}}$ values below $5 \mu \mathrm{M}$, but no toxicity was observed at $\mathrm{B}_{\mathrm{F}}$ values $\leq 1 \mu \mathrm{M}$. In three of the papers selected $(13,14,16)$, the stock UCB solution was markedly supersaturated, so that precipitation and degradation likely occurred; thus, the true threshold for UCB toxicity may have been lower than the calculated $B_{F}$ values. Another selected paper studied $\mathrm{B}_{\mathrm{F}}$ values below $5 \mu \mathrm{M}$, but there were no studies done at $\mathrm{B}_{\mathrm{F}}$ values between 383 and $1761 \mathrm{nM}$, so that the true threshold could not be evaluated (17).

Calculations. $\mathrm{B}_{\mathrm{F}}$ levels were calculated from a model that assumes independent binding of UCB to two sites on albumin, using equation $1(10)$, where $k_{1}$ and $k_{2}$ are the binding constants for the first and second sites, respectively:

$$
\frac{\mathrm{B}_{\mathrm{T}}-\mathrm{B}_{\mathrm{F}}}{[\mathrm{HSA}]}=\frac{\mathrm{B}_{\mathrm{F}} \times k_{1}}{1+\left(\mathrm{B}_{\mathrm{F}} \times k_{1}\right)}+\frac{\mathrm{B}_{\mathrm{F}} \times k_{2}}{1+\left(\mathrm{B}_{\mathrm{F}} \times k_{2}\right)}
$$

Applying the Solver function of Microsoft Excel 6.0 (Microsoft Corp, Redmond, WA, U.S.A.) to equation $1, \mathrm{~B}_{\mathrm{F}}$ values were calculated from the total $\mathrm{UCB}\left(\mathrm{B}_{\mathrm{T}}\right)$ and total albumin [HSA] concentrations given in the selected papers, using affinity constants of solutions containing comparable concentrations of delipidated HSA and chloride. The value for $k_{1}$ was set equal to the first site affinity constant $\left(\mathrm{K}_{\mathrm{F}}\right)$ of ${ }^{14} \mathrm{C}$-UCB for delipidated HSA, derived from serial ultrafiltration of ${ }^{14} \mathrm{C}$ UCB in solutions containing comparable HSA and chloride concentrations, after correction for the labeled degradation products of ${ }^{14} \mathrm{C}-\mathrm{UCB}$ that passed the filter (9). This is valid, because the ultrafiltration studies had intentionally been performed at UCB/HSA ratios of 0.25 or below (9), at which binding of UCB to the second, lower-affinity site is insignificant (10). $k_{2}$ was calculated as $k_{1} / 15=k_{2}(10)$.

Most of the papers in the meta-analysis added the UCB \pm HSA to cells incubated in protein-free DMEM, which has a total chloride concentration of $118 \mathrm{mM}$; two papers $(20,21)$ used a chloride concentration of only $1 \mathrm{mM}$. Because the $\mathrm{K}_{\mathrm{F}}$ values from the ultrafiltration studies had been obtained only in the presence of $50 \mathrm{mM}$ chloride or no chloride, $\mathrm{K}_{\mathrm{F}}$ values obtained at $50 \mathrm{mM}$ or $0 \mathrm{mM}$ chloride were applied, respectively. Based on published measurements of the affinity of chloride ions for delipidated HSA (18), these approximations may result in overestimation of $\mathrm{K}_{\mathrm{F}}$ by, at most, 14 to $26 \%$ (see "Discussion").

All but three of the papers used unpurified UCB. Only the studies from the Lisbon group (19-21) used UCB that was purified by alkaline extraction of impurities and recrystallization from chloroform (22). All studies that included HSA, including the reference ultrafiltration studies of UCB-HSA binding, used delipidated HSA (Sigma Chemical Co, St. Louis, MO, U.S.A.). In all studies, the UCB had been dissolved in $0.1-1.0 \mathrm{~N} \mathrm{NaOH}$, then added to the buffered solution of HSA (if used), and then neutralized with $\mathrm{HCl}$.

\section{RESULTS}

We report only comparisons of reported toxic effects of $\mathrm{UCB}$ with $\mathrm{B}_{\mathrm{F}}$ levels calculated from the total UCB, HSA, and chloride concentrations provided in the published papers that were selected for the meta-analysis. We performed no direct measurements of the $\mathrm{B}_{\mathrm{F}}$ levels in these media and no studies of the effects of UCB on cultured cells.

\section{Studies with Unpurified UCB}

Astroglial cells (Table 1). Cultured cerebral glial cells from rat embryos showed a significant decrease in mitochondrial function (MTT activity) when exposed for $2 \mathrm{~h}$ to $\mathrm{B}_{\mathrm{F}}$ levels of $500 \mathrm{nM}$ or higher (Fig. 1) (16). Trypan blue release by the same cells increased significantly at $\mathrm{B}_{\mathrm{F}}$ levels of $1560 \mathrm{nM}$, but not at $119 \mathrm{nM}$; intermediate $\mathrm{B}_{\mathrm{F}}$ levels were not tested. In contrast, cultured cerebral astrocytes from neonatal rats were damaged by $\geq 24-\mathrm{h}$ exposure to $\mathrm{B}_{\mathrm{F}}$ levels as low as $71 \mathrm{nM}$, exhibiting significant dose-related decreases in viability (increased LDH release) and mitochondrial function (MTT test) (Fig. 2) (23). A similar 24- to 48-h exposure of these cells to UCB likewise significantly increased LDH release, but the 
Table 1. Toxic effects of UCB on cultured rodent glial cells and astrocytes, with threshold $B_{F}$ levels

\begin{tabular}{|c|c|c|c|c|c|c|c|}
\hline $\begin{array}{l}\text { CNS region and cell type } \\
\text { Animal species }\end{array}$ & $\begin{array}{l}\mathrm{UCB} / \mathrm{HSA} \\
\text { mol ratio }\end{array}$ & $\begin{array}{c}\mathrm{Cl}^{-} \\
(\mathrm{mM})^{*}\end{array}$ & $\begin{array}{c}\text { Free } \mathrm{UCB}, \\
\mathrm{B}_{\mathrm{F}} \text { range }(\mathrm{nM})\end{array}$ & $\begin{array}{l}\text { Exposure } \\
\text { to UCB, (h) }\end{array}$ & $\begin{array}{l}\text { Threshold } \mathrm{B}_{\mathrm{F}} \\
\qquad(\mathrm{nM}) \dagger\end{array}$ & $\begin{array}{l}\text { Function tested, } \\
\text { change from control }\end{array}$ & Reference \\
\hline Cerebral glial cells & No HSA & NA & $10-10,000$ & 2 & 500 & MTT activity $\downarrow 41 \%$ & 16 \\
\hline $20-21$ day rat embryos & 0.5 or 2.0 & 118 & $53-4800$ & 1,2 & 4800,1560 & Trypan blue release $\uparrow 8.7,2.9 \times$ & \\
\hline Cerebral astrocytes & $0.5-1.0$ & 118 & $34-107$ & $24-72$ & 71 & LDH release $\uparrow 1.8-3.3 \times$ & 23 \\
\hline 2-d-old neonatal rat & $0.7-1.0$ & & $58-107$ & $24-72$ & 71 & MTT activity $\downarrow 48 \%$ & \\
\hline $\begin{array}{l}\text { Cerebral astrocytes } \\
\text { 2-d-old neonatal rat }\end{array}$ & 1.7 & 118 & $194-26,818$ & $24,36,48$ & 721 & LDH release $\uparrow 4.2,11.1,16.8 \times$ & 24 \\
\hline $\begin{array}{l}\text { Cerebral astrocytes } \\
\text { 2-d-old neonatal rat }\end{array}$ & No HSA & NA & $1,000-300,000$ & $1 \mathrm{~min}$ & 25,000 & $\mathrm{~T}_{3}$ uptake $\downarrow 18 \%$ & 15 \\
\hline $\begin{array}{l}\text { Cortical astrocytes } \\
\text { 2-d-old neonatal rat }\end{array}$ & $\begin{array}{c}0.2-3.0 \\
3.0\end{array}$ & 118 & $\begin{array}{c}33-1050 \\
6,060-29,807\end{array}$ & 0.25 & $\begin{array}{c}309 \\
6063 \S\end{array}$ & $\begin{array}{c}{\left[{ }^{3} \mathrm{H}\right] \text { glutamate uptake } \downarrow 37 \%} \\
\text { Apoptosis } \uparrow 5 \times\end{array}$ & $\begin{array}{l}19 \\
20\end{array}$ \\
\hline
\end{tabular}

* DMEM has total chloride concentration of $118 \mathrm{mM}$.

$\dagger$ Threshold $\mathrm{B}_{\mathrm{F}}$ is the lowest unbound UCB concentration tested that produced a significant $(p<0.05)$ change from control.

$\ddagger$ Only these studies used purified UCB.

$\S$ Apoptosis was not studied at lower $\mathrm{B}_{\mathrm{F}}$.

I Hoechst stain for nuclear fragmentation was used.

Abbreviations used: NA, not available; ${ }^{3} \mathrm{H}-\mathrm{T}$, tritiated thymidine.

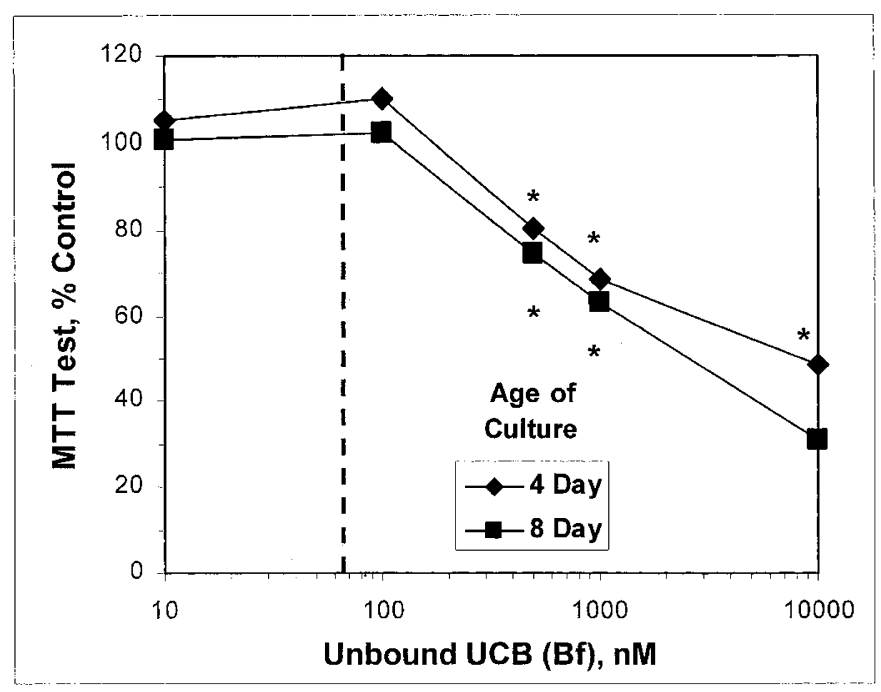

Figure 1. Effects on cultured embryonic rat cerebral glial cells of exposure for $2 \mathrm{~h}$ to 10 to $10,000 \mathrm{nM}$ of unpurified UCB in the absence of albumin. Impairment of mitochondrial function (MTT test) was similar in cells cultured for 4 or 8 d. ${ }^{*} p<0.05 v s$ control. Derived from Figure 4 of Amit and Brenner (16).

threshold $\mathrm{B}_{\mathrm{F}}$ level was $721 \mathrm{nM}$ (Fig. 3), with no effect at 194 $\mathrm{nM}(24)$.

Another study with cultured brain astrocytes from newborn rats, performed without albumin, tested $\mathrm{B}_{\mathrm{F}}$ values as low as 1 $\mu \mathrm{M}$, but found no effect on the uptake of $\mathrm{T}_{3}$ at $\mathrm{B}_{\mathrm{F}}$ of $10 \mu \mathrm{M}$ (15); at $\mathrm{B}_{\mathrm{F}} \geq 25 \mu \mathrm{M}, \mathrm{UCB}$ caused dose-dependent inhibition of $\mathrm{T}_{3}$ uptake, with a $\mathrm{K}_{\mathrm{i}}$ of $31 \mu \mathrm{M}$. Biliverdin, bilirubin ditaurate and bilirubin glucuronides were progressively more effective inhibitors than UCB, supporting the concept that the inhibition was competitive and not a result of cytotoxicity.

Neuronal cells (Table 2). In the absence of HSA, MTT activity was impaired after $24 \mathrm{~h}$ of exposure of embryonic rat hippocampal neurons to $250 \mathrm{nM} \mathrm{UCB}(p<0.05$; figure not shown) (25) and of 14-d embryonic rat forebrain neurons to

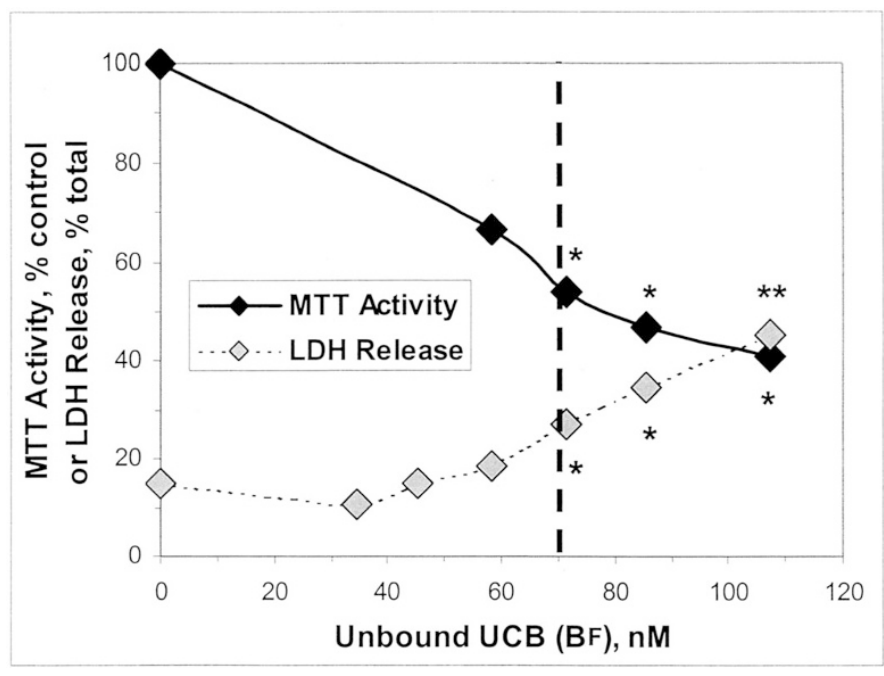

Figure 2. Effects on cultured neonatal rat astrocytes of exposure to varied concentrations of unpurified unbound $\mathrm{UCB}\left(\mathrm{B}_{\mathrm{F}}\right)$ for $24 \mathrm{~h}$. A significant decrease in both mitochondrial function (MTT activity) and membrane integrity (increased LDH release) occurred at $\mathrm{B}_{\mathrm{F}}$ levels at or above $71 \mathrm{nM}$, just above the aqueous solubility limit for UCB ( $70 \mathrm{nM}$, vertical dashed line). ${ }^{*} p$ $<0.05, * * p<0.01$. Derived from data of Chuniaud et al. (23).

UCB concentrations as low as $400 \mathrm{nM}$ (Fig. 4) (14) or $500 \mathrm{nM}$ (data not shown) (13). The last two studies also demonstrated that exposure to $500 \mathrm{nM} \mathrm{UCB}$ for 24 to $96 \mathrm{~h}$ caused a large decrease in $\left[{ }^{3} \mathrm{H}\right]$ thymidine incorporation, accompanied by increases in subsequent $\left[{ }^{3} \mathrm{H}\right]$ thymidine release and in apoptosis. $\left[{ }^{3} \mathrm{H}\right]$ leucine incorporation into cell protein was affected also after $6 \mathrm{~h}$, with a triphasic response (13). A line of mouse neuroblastoma cells exposed to UCB/HSA systems for $22 \mathrm{~h}$ showed significant, dose-related decreases in MTT activity and $\left[{ }^{3} \mathrm{H}\right]$ thymidine incorporation only at $\mathrm{B}_{\mathrm{F}}$ levels of $775 \mathrm{nM}$ and above (Fig. 5) (26). In a related paper from the same group (17), a line of rat neuroblastoma cells exhibited significant, multifunctional UCB toxicity after only $2-4 \mathrm{~h}$ of exposure to UCB/HSA systems, but only at $B_{F}$ levels in excess of 1700 


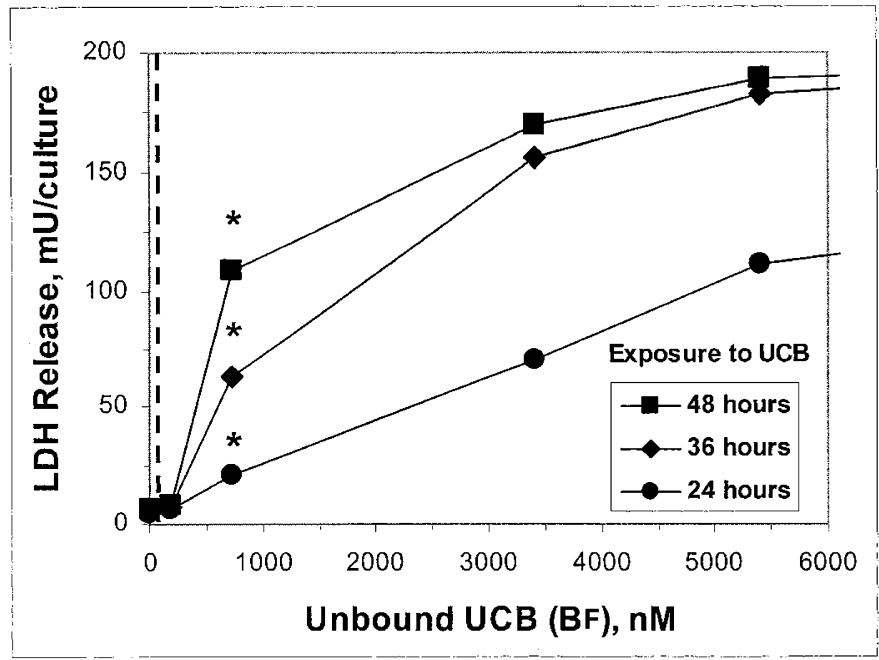

Figure 3. Effects on cultured neonatal rat astrocytes of exposure for 24, 36, or $48 \mathrm{~h}$ to concentrations of unpurified unbound $\mathrm{UCB}\left(\mathrm{B}_{\mathrm{F}}\right)$ ranging from 194 to $26,818 \mathrm{nM}$. $* p<0.05$ at threshold $\mathrm{B}_{\mathrm{F}}$ of $721 \mathrm{nM}$, as well as all higher concentrations. The effects above $\mathrm{B}_{\mathrm{F}}$ of 6000 (not shown) are similar to those at $5400 \mathrm{nM}$. Derived from data of Rhine et al. (24).

$\mathrm{nM}$; the true thresholds may have been much lower, because $\mathrm{B}_{\mathrm{F}}$ levels between 400 and $1700 \mathrm{nM}$ were not tested. The functions impaired included ${ }^{42} \mathrm{~K}^{+}$uptake, $\left[{ }^{3} \mathrm{H}\right]$ thymidine incorporation into DNA, MTT activity, and incorporation of $\left[{ }^{35} \mathrm{~S}\right]$ methionine into cellular protein.

\section{Studies with Purified UCB}

Cortical astrocytes from neonatal rats showed a dose-related decrease in uptake of $\left[{ }^{3} \mathrm{H}\right]$ glutamate after only $15 \mathrm{~min}$ of exposure to purified $\mathrm{UCB}$ at $\mathrm{B}_{\mathrm{F}}$ levels above $300 \mathrm{nM}$ (Table 1 and Fig. 6) (19). Apoptosis was observed also, but was studied only at $\mathrm{B}_{\mathrm{F}}$ levels of $6063 \mathrm{nM}$ or higher (20). Neonatal and embryonic cortical neurons from rats exhibited dose-related apoptosis when exposed for $4 \mathrm{~h}$ to $\mathrm{B}_{\mathrm{F}}$ levels of $85 \mathrm{nM}$ or higher (Table 2 and Fig. 7) $(20,21)$. At and above this threshold $B_{F}$ level, the apoptosis was accompanied by release of cytochrome $c$ from mitochondria, as well as activation of caspase-3, and cleavage of ADP-ribose polymerase (21). By contrast, other mitochondrial changes (translocation of Bax and collapse of membrane potential) were not observed until $\mathrm{B}_{\mathrm{F}}$ levels reached $50 \mu \mathrm{M}$.

\section{DISCUSSION}

Applying the corrected affinity constants $\left(\mathrm{K}_{\mathrm{F}}\right)(9), \mathrm{B}_{\mathrm{F}}$ exceeds maximum aqueous UCB solubility $(70 \mathrm{nM})$ at $\mathrm{B}_{\mathrm{T}}$ well below those at which the first binding site on HSA becomes saturated (Fig. 8A). At the normal adult HSA concentration of $600 \mu \mathrm{M}$, this occurs when $\mathrm{B}_{\mathrm{T}}$ exceeds $80-85 \mu \mathrm{M}(4.7-5.0$ $\mathrm{mg} / \mathrm{dL}$; Fig. $8 B$ ). Except in Crigler-Najjar syndrome, $\mathrm{B}_{\mathrm{T}}$ levels are rarely this high in adults with unconjugated hyperbilirubinemia. At the $25 \%$ lower mean albumin concentrations in newborn plasma (5), supersaturation would occur at $\mathrm{B}_{\mathrm{T}}$ above $82 \mu \mathrm{M}(>4.8 \mathrm{mg} / \mathrm{dL}$; Fig. $8 B$ ), values commonly observed in uncomplicated neonatal hyperbilirubinemia. Thus, except possibly when HSA levels are low in jaundiced patients with cirrhosis, only neonates are exposed to plasma $\mathrm{B}_{\mathrm{F}}$ levels above aqueous solubility.

At $B_{F}$ levels above saturation, self-aggregation of UCB diacid must occur, progressing through three stages (7, 27-29). Oligomers of UCB diacid appear just above saturation; although they are too small to precipitate, they can dissociate reversibly and serve as a reservoir to replenish UCB monomers removed by cells. At higher UCB concentrations, larger colloidal aggregates form, stabilized by UCB mono- and dianions adsorbed on their surfaces (7). These microsuspensions may precipitate with prolonged standing (ripening) or neutralization of the charges by a decrease in $\mathrm{pH}$ (28). At yet higher UCB concentrations, coarser aggregates appear that precipitate spontaneously. Limited available data suggests that metastable aggregates are present at $\mathrm{B}_{\mathrm{F}}$ as low as $1-2 \mu \mathrm{M}$ at $\mathrm{pH} 7.0$ to 7.4 , but probably not at $500 \mathrm{nM}(28,29)$.

Our recalculated $\mathrm{B}_{\mathrm{F}}$ levels for published in vitro studies (Tables 1 and 2) reveal that neurotoxic effects of even purified $\mathrm{UCB}$ can be observed at $\mathrm{B}_{\mathrm{F}}$ levels ranging from slightly above to 11 times aqueous solubility $(71-770 \mathrm{nM})$, although higher thresholds were obtained in some of the studies. Only a few of the original papers attempted to calculate or measure free bilirubin concentrations, and, when doing so, they used methods that have been shown to be flawed, as discussed elsewhere $(8,9)$. The variation of more than 10 -fold among studies in our recalculated toxic thresholds for unbound bilirubin concentrations (Tables 1 and 2 ) is not unexpected, as the 12 papers used different cell systems from different species (26) of differing maturity, different cell functions, and different durations of culture (16) and exposure to UCB. Thus, the variable thresholds may simply reflect different susceptibilities of different cell systems to different types of injury.

Minor components in the DMEM, including those released by the cells themselves, might have influenced binding also. Although the different batches of delipidated HSA may have differed somewhat in their affinities for UCB, we have found that the binding affinity for UCB among four different batches of delipidated albumin from the same manufacturer (Sigma Chemical Co) varied by less than $4 \%$ (Ostrow JD, unpublished data). Thus, only a small error in $\mathrm{B}_{\mathrm{F}}$ is introduced by our assumption that the binding affinity of the HSA used in our ultrafiltration study (9) is representative of the batches used in the studies in the meta-analysis.

Figures 2, 5, and 6 reveal a trend toward decreased viability or function at $\mathrm{B}_{\mathrm{F}}$ levels below those at which a statistically significant impairment was attained. In all four cases, if those trends are assumed to be real effects, the resultant lower thresholds are still all slightly below (Fig. 2 and 6) to modestly above (Fig. 5) the solubility limit for unbound UCB. Some figures show gradual declines in function with increasing $\mathrm{B}_{\mathrm{F}}$ levels, whereas in others, the threshold appears to be abrupt. Such differences, however, may be more apparent than real, depending on whether enough data points were obtained both above and below the true threshold.

Although, for reasons noted above, the thresholds varied with different studies and the responses were not uniform, our findings clearly establish that that marked supersaturation and precipitation of UCB are not necessary to produce toxicity to 
Table 2. Toxic effects of UCB on cultured rodent neuronal cells, with threshold $B_{F}$ levels

\begin{tabular}{|c|c|c|c|c|c|c|c|}
\hline $\begin{array}{l}\text { CNS region and cell type } \\
\text { Animal species }\end{array}$ & $\begin{array}{l}\mathrm{UCB} / \mathrm{HSA} \\
\text { mol ratio }\end{array}$ & $\begin{array}{c}\mathrm{Cl}^{-} \\
(\mathrm{mM})^{*}\end{array}$ & $\begin{array}{c}\text { Free } \mathrm{UCB}, \\
\mathrm{B}_{\mathrm{F}} \text { range }(\mathrm{nM})\end{array}$ & $\begin{array}{l}\text { Exposure to } \\
\text { UCB (h) }\end{array}$ & $\begin{array}{l}\text { Threshold } B_{F} \\
(\mathrm{nM}) \dagger\end{array}$ & $\begin{array}{l}\text { Function tested, } \\
\text { change from control }\end{array}$ & Reference \\
\hline $\begin{array}{l}\text { Hippocampal neurons } \\
17-d \text { embryonic rat }\end{array}$ & No HSA & NA & $25-250$ & 24 & 250 & MTT activity $\downarrow 26 \%$ & 25 \\
\hline $\begin{array}{l}\text { Forebrain neurons } \\
\text { 14-d embryonic rat }\end{array}$ & No HSA & NA & $250-5000$ & $\begin{array}{l}72 \\
96\end{array}$ & $\begin{array}{l}400 \\
500\end{array}$ & 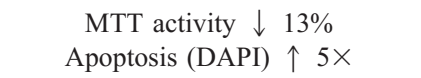 & 14 \\
\hline $\begin{array}{l}\text { Forebrain neurons } \\
\text { 14-d embryonic rat }\end{array}$ & No HSA & NA & 500 only & $\begin{array}{c}48,72,96 \\
96 \\
24,96 \\
24,96\end{array}$ & $\begin{array}{l}\text { Only } 500 \\
\text { tested }\end{array}$ & $\begin{array}{c}\text { MTT activity } \downarrow 18,21,26 \% \\
\text { Apoptosis (DAPI) } \uparrow 6.8 \times \\
{\left[{ }^{3} \mathrm{H}\right] \text { leucine incorp. } \downarrow 39,41 \%} \\
\text { 2-DG uptake } \downarrow 66,35 \%\end{array}$ & 13 \\
\hline $\begin{array}{l}\text { Neuroblastoma cells } \\
\text { mouse (NBR10A line) }\end{array}$ & $0.8-1.5$ & 118 & $100-3900$ & 22 & $\begin{array}{l}775 \vdots \\
786 \ddagger\end{array}$ & $\begin{aligned} \text { MTT activity } & \downarrow 41 \% \\
{ }^{3} \mathrm{H}-\mathrm{T} \text { incorporation } & \downarrow 58 \%\end{aligned}$ & 26 \\
\hline $\begin{array}{l}\text { Neuroblastoma cells } \\
\text { rat (N115 line) }\end{array}$ & $\begin{array}{l}0.8,1.5 \\
1.5 \text { only }\end{array}$ & $\begin{array}{l}118 \\
118\end{array}$ & $\begin{array}{l}301-383 \text { and } \\
1766-2378 \\
2113 \text { only } \\
2113 \text { only }\end{array}$ & $\begin{array}{l}2,4 \\
2,4 \\
1-4 \\
1-4\end{array}$ & $\begin{array}{l}1766 \\
2378 \\
\text { Only } 2113 \\
\text { tested }\end{array}$ & $\begin{array}{c}{ }^{42} \mathrm{~K}^{+} \text {uptake } \downarrow 26 \% \text { (4 h only) } \\
{ }^{3} \mathrm{H}-\mathrm{T} \text { incorporation } \downarrow 23,50 \% \\
\text { MTT activity } \downarrow 13-63 \% \\
{\left[{ }^{35} \text { S }\right] \text { methionine incorp. } \downarrow 23-57 \%}\end{array}$ & 17 \\
\hline $\begin{array}{l}\text { Cortical neurons } \S \\
\text { neonatal and embryonic } \\
\text { rat }\end{array}$ & $0.5-3.0$ & 1 & $85-2900$ & 4 & 85 & Apoptosis $\| \uparrow 2 \times \mathbb{q}$ & $\begin{array}{l}20 \\
21\end{array}$ \\
\hline
\end{tabular}

* DMEM has total chloride concentration of $118 \mathrm{mM}$.

$\dagger$ Threshold $\mathrm{B}_{\mathrm{F}}$ is the lowest unbound UCB concentration tested that produced a significant $(p<0.05)$ change from control.

$\$$ Rat neuroblastoma cell line N115 was tested also and showed no effect on MTT activity until $\mathrm{B}_{\mathrm{F}}$ was 2600 , but virtually identical sensitivity to the mouse line when $\left[{ }^{3} \mathrm{H}\right]$ thymidine incorporation was tested.

$\S$ Only these studies used purified UCB.

I Release of cytochrome $c$ from mitochondria, as well as activation of caspase-3, and cleavage of ADP-ribose polymerase were demonstrated also at the same threshold $\mathrm{B}_{\mathrm{F}}$ level.

$\|$ Hoechst stain for nuclear fragmentation was used.

Abbreviations used: NA, not available; DAPI, 4', 6-diamidino-2-phenylindole; 2-DG, 2-deoxyglucose; ${ }^{3} \mathrm{H}-\mathrm{T}$, tritiated thymidine.

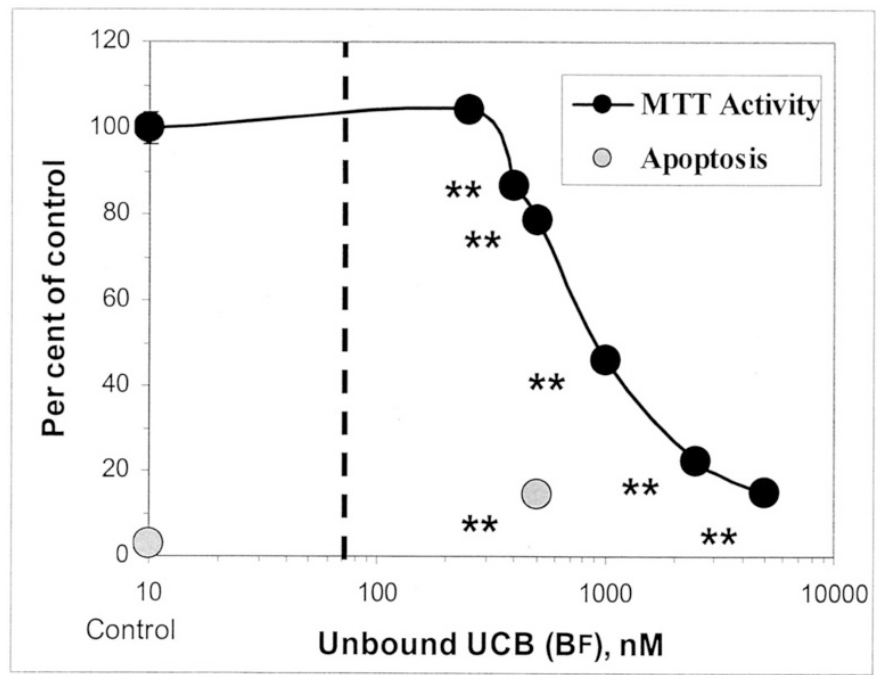

Figure 4. Effects on cultured forebrain neurons from 14-d-old rat embryos of exposure for $72-96 \mathrm{~h}$ to varied concentrations of unpurified unbound UCB $\left(\mathrm{B}_{\mathrm{F}}\right)$. A significant decrease in mitochondrial function (MTT activity) was observed at $\mathrm{B}_{\mathrm{F}}$ levels at or above $400 \mathrm{nM}$, and an increase in apoptosis at a $\mathrm{B}_{\mathrm{F}}$ level of $500 \mathrm{nM}, 5.7$ and 7.1 times, respectively, the aqueous solubility limit for UCB $(70 \mathrm{nM}$, vertical dashed line $) .{ }^{*} p<0.01$. Derived from data of Grojean et al. (14).

CNS cells. This renders untenable the long-accepted concept that only coarse UCB aggregates, which may include coprecipitated albumin, are involved in early UCB toxicity (7). Even allowing for potential moderate inaccuracies in our calculated

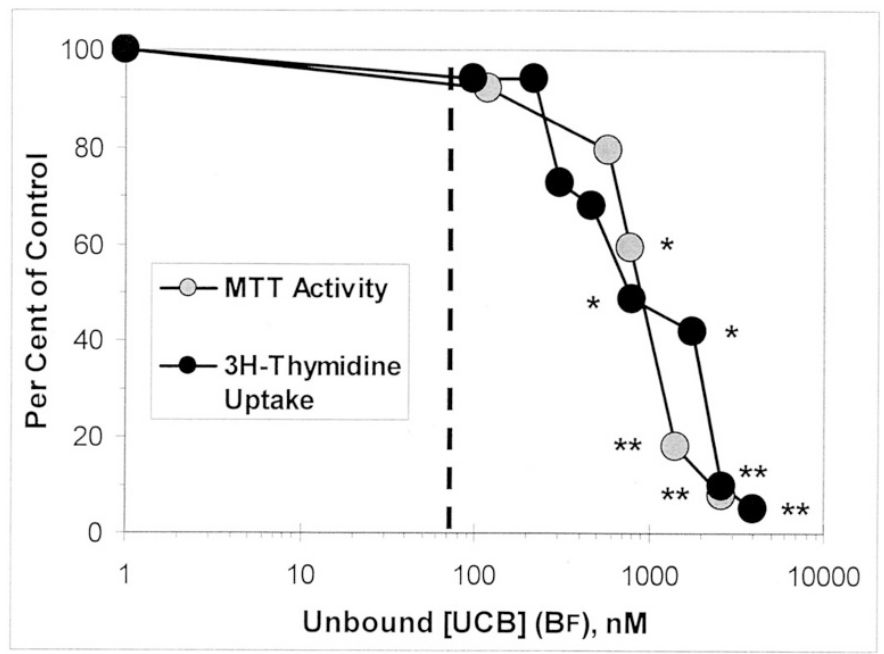

Figure 5. Effects on cultured mouse neuroblastoma cells (NBR10A line) of exposure for $22 \mathrm{~h}$ to varied concentrations of unpurified unbound $\mathrm{UCB}\left(\mathrm{B}_{\mathrm{F}}\right)$. A significant decrease in both mitochondrial function (MTT activity) and $\left[{ }^{3} \mathrm{H}\right]$ thymidine uptake occurred at $\mathrm{B}_{\mathrm{F}}$ levels at or above $780 \mathrm{nM}, 11$ times the aqueous solubility limit for $\mathrm{UCB}\left(70 \mathrm{nM}\right.$, vertical dashed line). ${ }^{*} p<0.05, * * p$ $<0.01$. Derived from data of Schiff et al. (26).

values of unbound bilirubin (9), our findings strongly suggest that toxicity develops only near or above the aqueous saturation limit of $70 \mathrm{nM}$, a range in which only UCB monomers, soluble oligomers, and metastable small colloids are likely to be present. By contrast, $\mathrm{B}_{\mathrm{F}}$ levels well below $70 \mathrm{nM}$ [aqueous 


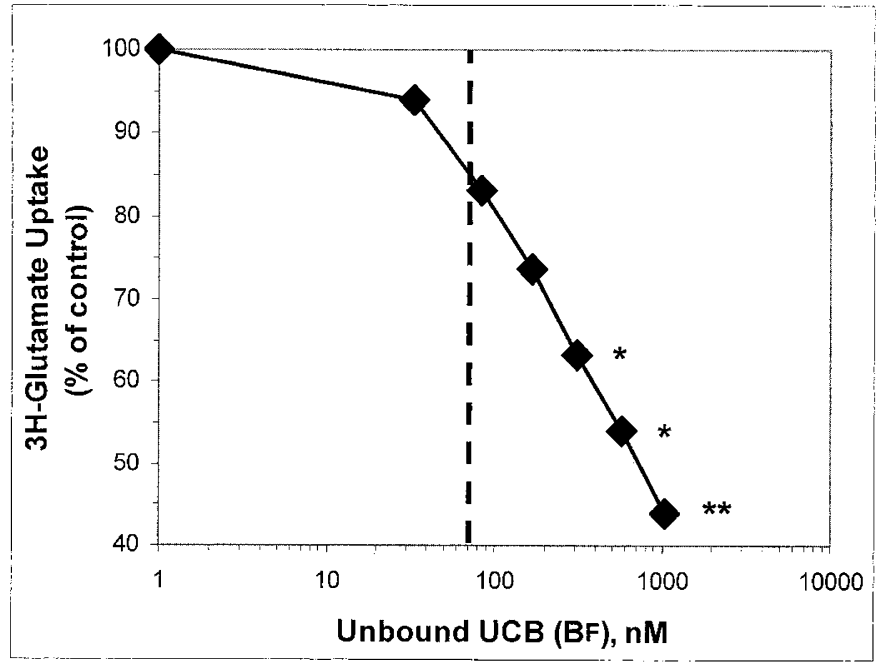

Figure 6. Effects on cultured cortical astrocytes from 2-d-old neonatal rats of exposure for 15 min to varied concentrations of purified unbound $\mathrm{UCB}\left(\mathrm{B}_{\mathrm{F}}\right)$. A significant decrease in $\left[{ }^{3} \mathrm{H}\right]$ glutamate uptake was observed at $\mathrm{B}_{\mathrm{F}}$ levels at or above $309 \mathrm{nM}, 4.4$ times the aqueous solubility limit for UCB $(70 \mathrm{nM}$, vertical dashed line). ${ }^{*} p<0.05,{ }^{* *} p<0.01$. Derived from data of Silva et al. $(19,20)$.

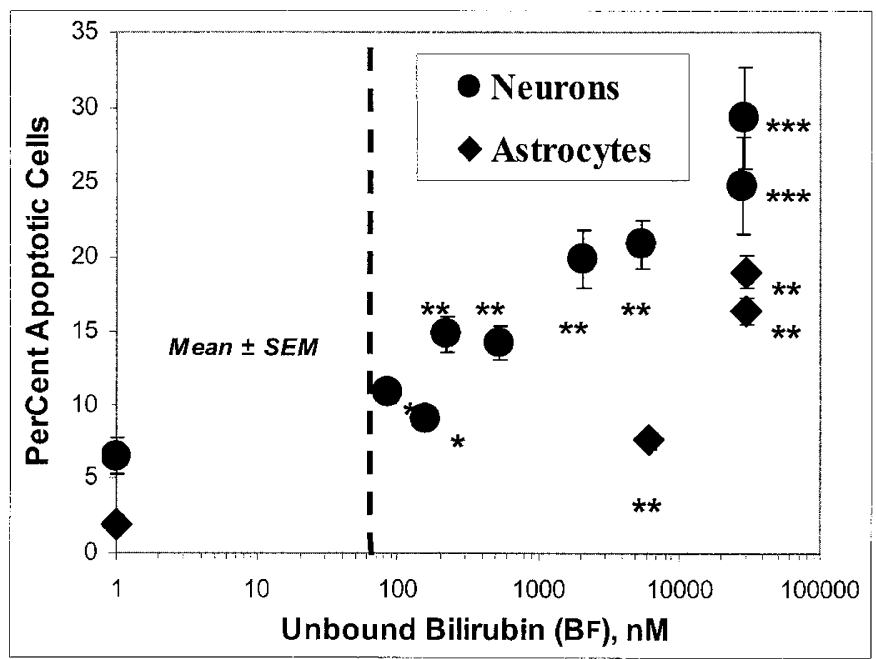

Figure 7. Effects on cultured cortical neurons and astrocytes from neonatal and embryonic rats of exposure to varied concentrations of purified unbound $\mathrm{UCB}\left(\mathrm{B}_{\mathrm{F}}\right)$ for $4 \mathrm{~h}$. A significant increase in apoptosis of neurons occurred at $\mathrm{B}_{\mathrm{F}}$ levels at or above $85 \mathrm{nM}$, slightly above the aqueous solubility limit for UCB $(70 \mathrm{nM}$, vertical dashed line). Astrocytes were affected at $6063 \mathrm{nM}$, but lower $\mathrm{B}_{\mathrm{F}}$ levels were not tested. $* p<0.05,{ }^{* *} p<0.01,{ }^{* * *} p<0.001$. Derived from data of Silva et al. (20) and Rodrigues et al. (21).

saturation (30)] appear to protect CNS cells against oxidative damage $(25,31)$, and this protection is lost because of the countervailing toxic effects of UCB at higher $\mathrm{B}_{\mathrm{F}}$ levels (25).

At these relatively low $\mathrm{B}_{\mathrm{F}}$ levels, both astrocytes and neurons were susceptible to impairment of mitochondrial functions (MTT activity and apoptosis), whereas diminished incorporation of $\left[{ }^{3} \mathrm{H}\right]$ thymidine was reported only for neurons. These toxic effects can account for the structural features of apoptosis that appear in the cerebellum and cochlear nucleus of jaundiced Gunn rat pups (32-34) and in the basal ganglia of kernicteric human infants (5). These early changes appear well before
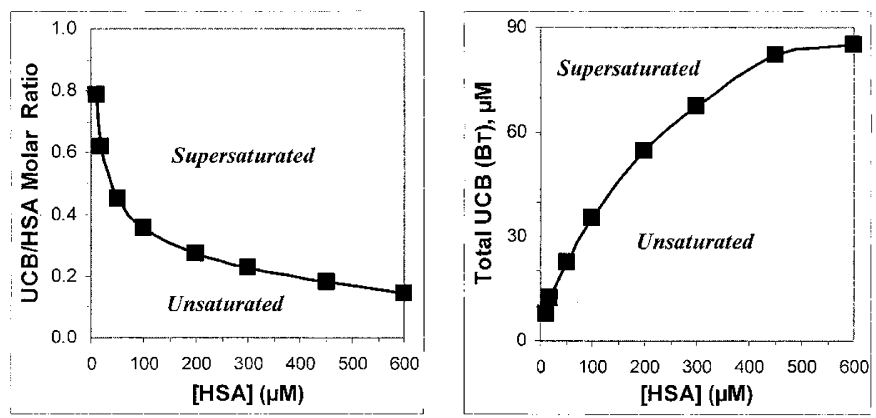

Figure 8. UCB/HSA ratios (left) and total UCB concentrations (right) at which calculated $\mathrm{B}_{\mathrm{F}}$ values equal the aqueous solubility of unbound $\mathrm{UCB}$ at $\mathrm{pH} 7.4$ over a range of albumin (HSA) concentrations. Areas above each curve are supersaturated with unbound $\mathrm{UCB}$, whereas areas below the line are unsaturated. At mean normal plasma albumin concentrations of $450 \mu \mathrm{M}$ for neonates and $600 \mu \mathrm{M}$ for adults, supersaturation occurs at UCB/HSA ratios as low as 0.2 and at total UCB concentrations above $80 \mu \mathrm{M}$. $\mathrm{B}_{\mathrm{F}}$ values were calculated by applying corrected affinity constants of UCB for HSA in the presence of chloride (9) at the albumin concentrations indicated. The calculations (equation 1) assumed independent binding of UCB to two sites on albumin (10).

peak UCB levels are attained, but ultimately progress to atrophy of these CNS regions.

The modestly supersaturated $\mathrm{B}_{\mathrm{F}}$ levels also affected astrocyte membranes, as shown by increased LDH release (23) (Fig. 2 ) and impaired $\left[{ }^{3} \mathrm{H}\right]$ glutamate uptake (Fig. 6) (19). The extremely brief period of exposure to UCB probably explains why Warr et al. (35) did not detect changes in glutamate transporters, $N$-methyl-D-aspartate receptors, or electrical currents in retinal glial cells from salamanders after treatment with $10 \mu \mathrm{M}$ UCB for only $10-50 \mathrm{~s}$.

Effects of purified UCB on the membrane structure of neurons (21) and mitochondria (20) have been observed, however, only at highly supersaturated $\mathrm{B}_{\mathrm{F}}$ levels in the micromolar range, at which UCB precipitation is expected. This fits with historic concepts that precipitation of UCB in cell membranes alters membrane fluidity and the activity of integral membrane proteins (7), but it is problematic as to whether this is relevant to the modestly elevated $\mathrm{B}_{\mathrm{F}}$ levels associated with the reversible stages of bilirubin encephalopathy. Monomers of UCB diacid cannot penetrate deeply into membranes (36), but bind near the surface of the outer leaflet of the membrane (37-39). The resultant modest perturbation of membrane structure might be a factor in the early cellular toxicity of clinically relevant concentrations of UCB (39).

Ahlfors (8) applied a peroxidase-diazo method to reassess $\mathrm{B}_{\mathrm{F}}$ for historic data on plasma $\mathrm{B}_{\mathrm{T}}$ and HSA concentrations in jaundiced neonates and concluded that kernicterus was likely only when $\mathrm{B}_{\mathrm{F}}$ levels exceeded $60 \mathrm{nM}(40)$, in apparent agreement with our results for in vitro systems. There are, however, important differences between plasma or serum and in vitro systems that limit comparisons between his study and ours. Plasma contains additional proteins that bind UCB, such as apo $\mathrm{D}(41)$, so that $\mathrm{B}_{\mathrm{F}}$ levels in plasma are lower than those in solutions containing the same concentration of purified albumin (42). On the other hand, FFA and other substances not present in defined solutions containing delipidated albumin may inhibit the binding of UCB to albumin (7). Finally, in vivo, 
neurons and astrocytes are not exposed directly to plasma, but are separated by the blood-brain and blood-cerebrospinal fluid barriers that may limit penetration of unbound UCB into the CNS (6). Thus, the media to which the CNS cells are exposed in vitro are the equivalent of the cerebrospinal fluid and extracellular fluid in the brain, where, in jaundiced Gunn rats, total UCB concentrations may be only one fifth those in plasma (43) and albumin concentrations are much lower than plasma. Overall, therefore, the threshold $\mathrm{B}_{\mathrm{F}}$ levels for UCB neurotoxicity are likely to be higher in plasma in vivo than in defined albumin solutions in vitro.

\section{CONCLUSIONS}

Because of the above-noted differences between in vitro and in vivo systems, as well as interspecies differences, it remains to be determined whether, to fully prevent bilirubin encephalopathy, treatment of neonatal hyperbilirubinemia should be instituted at plasma UCB levels lower than those that are currently recommended $(5,44)$. Nonetheless, our findings favor a role for small, soluble UCB aggregates, present at moderately supersaturated $\mathrm{B}_{\mathrm{F}}$ levels, in the often-reversible damage to mitochondria, and possibly plasma membranes of CNS cells that characterize the early stages of bilirubin encephalopathy.

\section{REFERENCES}

1. Dore S, Takahashi M, Ferris CD, Zakhary R, Hester LD, Guastella D, Snyder SH 1999 Bilirubin, formed by activation of heme oxygenase-2, protects neurons agains oxidative stress injury. Proc Natl Acad Sci USA 96:2445-2450

2. Stocker R, McDonagh AF, Glazer AN, Ames BN 1990 Antioxidant activities of bile pigments: biliverdin and bilirubin. Methods Enzymol 186:301-309

3. McDonagh AF 1990 Is bilirubin good for you? Clin Perinatol 17:359-370

4. Schneider AP 1986 Breast milk jaundice in the newborn. A real entity. JAMA 255:3270-3274

5. Gourley GR 1997 Bilirubin metabolism and kernicterus. Adv Pediatr 44:173-229

6. Wennberg RP 2000 The blood-brain barrier and bilirubin encephalopathy. Cell Mol Neurobiol 20:97-109

7. Brodersen R 1979 Binding of bilirubin to albumin; implications for prevention of bilirubin encephalopathy in the newborn. CRC Crit Rev Clin Lab Sci 11:305-399

8. Ahlfors CE 2000 Measurement of plasma unbound unconjugated bilirubin. Anal Biochem 279:130-135

9. Weisiger RA, Ostrow JD, Koehler RK, Webster CC, Mukerjee P, Pascolo L, Tiribelli C 2001 Affinity of human serum albumin for bilirubin varies with albumin concentration and buffer composition: results of a novel ultrafiltration method. J Biol Chem 276:29953-29960.

10. Brodersen R 1986 Aqueous solubility, albumin binding and tissue distribution of bilirubin. In: Ostrow JD (ed) Bile Pigments and Jaundice: Molecular, Metabolic and Medical Aspects. Marcel Dekker, New York, pp 157-181

11. Ostrow JD, Tiribelli C 2001 New concepts in bilirubin neurotoxicity and the need for studies at clinically relevant bilirubin concentrations. [editorial] J Hepatology 34:467-470

12. Ostrow JD, Pascolo L, Tiribelli C 2002 Mechanisms of bilirubin neurotoxicity. [editorial] Hepatology 35:1277-1280

12a.Silberberg DH, Johnson LH, Ritter L 1970 Factors influencing toxicity of bilirubin in cerebellum tissue culture. J Pediatr 77:386-396

12b.Silberberg DH, Johnson LH, Schutta H, Ritter L 1970 Effects of photodegradation products of bilirubin on myelinating cerebellum cultutres. J Pediatr 77:613-618

13. Grojean S, Lievre V, Koziel V, Vert P, Daval JL 2001 Bilirubin exerts additional toxic effects in hypoxic cultured neurons from the developing rat brain by the recruitment of glutamate neurotoxicity. Pediatr Res 49:507-513

14. Grojean S, Koziel V, Vert P, Daval JL 2000 Bilirubin induces apoptosis via activation of NMDA receptors in developing rat brain neurons. Exp Neurol 166:334-341
15. Chantoux F, Chuniaud L, Dessante M, Trivin F, Blondeau JP, Francon J 1993 Competitive inhibition of thyroid hormone uptake into cultured rat brain astrocytes by bilirubin and bilirubin conjugates. Mol Cell Endocrinol 97:145-151

16. Amit Y, Brenner T 1993 Age-dependent sensitivity of cultured rat glial cells to bilirubin toxicity. Exp Neurol 121:248-255

17. Amit Y, Chan G, Fedunec S, Poznansky MJ, Schiff D 1989 Bilirubin toxicity in a neuroblastoma cell line N-115: I. Effects on $\mathrm{Na}^{+} \mathrm{K}^{+}$ATPase, $\left[{ }^{3} \mathrm{H}\right]$-thymidine uptake, $\mathrm{L}-\left[{ }^{35} \mathrm{~S}\right]-$-methionine incorporation, and mitochondrial function. Pediatr Res 25:364368

18. Scatchard G, Scheinberg IH, Armstrong Jr SH 1950 Physical chemistry of protein solutions. IV. The combination of human serum albumin with chloride ion. J Am Chem Soc 72:535-540

19. Silva RFM, Mata LR, Gulbenkian S, Brito A, Tiribelli C, Brites D 1999 Inhibition of glutamate uptake by unconjugated bilirubin in cultured rat astrocytes: role of concentration and $\mathrm{pH}$. Biochem Biophys Res Commun 265:67-72

20. Silva RFM, Rodrigues CMP, Brites D 2001 Bilirubin-induced apoptosis in cultured rat neural cells is aggravated by chenodeoxycholic acid but prevented by ursodeoxycholic acid. J Hepatol 34:402-408

21. Rodrigues CMP, Sola S, Brites D 2002 Bilirubin induces apoptosis via the mitochondrial pathway in developing rat brain neurons. Hepatology 35:1186-1195

22. McDonagh AF, Assisi F 1972 The ready isomerization of bilirubin-IX $\alpha$ in aqueous solution. Biochem J 129:797-800

23. Chuniaud L, Dessante M, Chantoux F, Blondeau JP, Francon J, Trivin F 1996 Cytotoxicity of bilirubin for human fibroblasts and rat astrocytes in culture. Effect of the ratio of bilirubin to serum albumin. Clin Chim Acta 256:103-114

24. Rhine WD, Schmitter SP, Yu AC, Eng LF, Stevenson DK 1999 Bilirubin toxicity and differentiation of cultured astrocytes. J Perinatol 19:206-211

25. Dore S, Snyder SH 1999 Neuroprotective action of bilirubin against oxidative stress in primary hippocampal cultures. Ann NY Acad Sci 890:167-172

26. Schiff D, Chan G, Poznansky MJ 1985 Bilirubin toxicity in neural cell lines N115 and NBR10A. Pediatr Res 19:908-911

27. Lee KS, Gartner LM 1976 Spectrophotometric characteristics of bilirubin Pediatr Res 10:782-788

28. Siam M, Blaha G, Lehner H 1998 Maximum binding capacity of serum albumin for bilirubin is one, as revealed by circular dichroism. J Chem Soc Perkin Trans II: $853-856$

29. Mukerjee P, Ostrow JD, Tiribelli C 2002 Low solubility of unconjugated bilirubin in dimethylsulfoxide-water systems: implications for $\mathrm{pK}_{a}$ determinations. BMC Biochemistry $3: 17$

30. Hahm JS, Ostrow JD, Mukerjee P, Celic L 1992 Ionization and self-association of unconjugated bilirubin, determined by rapid solvent partition from chloroform, with further studies of bilirubin solubility. J Lipid Res 33:1123-1137

31. Barañano DE, Rao M, Ferris CD, Snyder SH 2002 Biliverdin reductase: a major physiologic cytoprotectant. Proc Natl Acad Sci USA 99:16093-16098

32. Schutta HS, Johnson LH 1967 Bilirubin encephalopathy in the Gunn rat: a fine structure study of the cerebellar cortex. J Neuropathol Exp Neurol 26:377-396

33. Yamamura H, Takagishi Y 1993 Cerebellar hypoplasia in the hyperbilirubinemic Gunn rat: morphological aspects. Nagoya J Med Sci 55:11-21

34. Conlee JW, Shapiro SM 1997 Development of cerebellar hypoplasia in jaundiced Gunn rats: a quantitative light microscopic analysis. Acta Neuropathol (Berl) 93:450460

35. Warr O, Mort D, Attwell D 2000 Bilirubin does not modulate ionotropic glutamate receptors or glutamate transporters. Brain Res 879:13-16

36. Ostrow JD, Mukerjee P, Tiribelli C 1994 Structure and binding of unconjugated bilirubin: relevance for physiological and pathophysiological function. J Lipid Res $35: 1715-1737$

37. Cestaro B, Cervato G, Ferrari S, Di Silvestro G, Monti D, Manitto P 1983 Interaction of bilirubin with small unilamellar vesicles of dipalmitoylphosphatidylcholine. Ital J Biochem 32:318-329

38. Zucker SD, Goessling W, Bootle EJ, Sterritt C 2001 Localization of bilirubin in phospholipid bilayers by parallax analysis of fluorescence quenching. J Lipid Res 42:1377-1388

39. Brito MA, Silva RFM, Tiribelli C, Brites D 2000 Assessment of bilirubin toxicity to erythrocytes. Implication in neonatal jaundice management. Eur $\mathrm{J}$ Clin Invest 30:239-247

40. Ahlfors CE 2001 Benzyl alcohol, kernicterus, and unbound bilirubin. J Pediatr 139:317-319

41. Goessling W, Zucker SD 2000 Role of apolipoprotein D in the transport of bilirubin in plasma. Am J Physiol Gastrointest Liver Physiol 279:G356-G365

42. Ahlfors CE 1981 Effect of serum dilution on apparent unbound bilirubin concentration as measured by the peroxidase method. Clin Chem 27:692-696

43. Rodriguez Garay EA, Scremin OU 1971 Transfer of bilirubin- ${ }^{14} \mathrm{C}$ between blood, cerebrospinal fluid, and brain tissue. Am J Physiol 221:1264-1270

44. Dennery PA, Seidman DS, Stevenson DK 2001 Neonatal hyperbilirubinemia. N Engl J Med 344:581-590 